ISSN 0206-5657. Вісник Львівського університету. Серія біологічна. 2018. Випуск 78. С. 73-79 Visnyk of the Lviv University. Series Biology. 2018. Issue 78. P. 73-79

\title{
HERBARIUM (AA) OF THE INSTITUTE OF BOTANY AND PHYTOINTRODUCTION: ESTABLISHMENT, PROSPECTS
}

\author{
G. Sitpayeva, S. Mukhtubayeva, G. Kudabayeva \\ RSE “Institute of Botany and Phytointroduction" of RK CN MES \\ 35 D, Timiryazev St., Almaty 050040, Kazakhstan \\ e-mail: sitpaeva@mail.ru,mukhtubaeva@mail.ru,kgm_anita@mail.ru
}

\begin{abstract}
This article provide information about the Herbarium Collection of the Institute of Botany and Phyto-Inoduct (AA)/A list of measures to replenish and preserve herbarium specimens is given. The significance of Herbarium as the main tool for studying the biological diversity of the flora of Kazakhstan is substantiated.

Keywords: The herbarium of the Institute of Botany and Phytointroduction, the collections, the botanical collections, the taxa
\end{abstract}

The botanical collections, comprising the foundation of academic knowledge of biological diversity are deemed to be one of the expressions of the national culture and the priceless national heritage. It is out of such unique collections that the public prestige is formed. The herbarium of the Institute of Botany and Phytointroduction of RK MES is the part of the national heritage of our Republic.

The herbarium of the Institute is part of the main global herbariums and has an international index of AA. The herbarium represents the only storage of the botanical collections in the Republic where the of the flora of Kazakhstan is most fully represented. At present about 259000 herbarium samples of moss, fungi, gymnosperms, angiosperm plants, 150000 samples of fungi and lichens are stored in the Herbarium.

Within the global context of preservation of biodiversity Kazakhstan holds a special place, both due to the vast nature of its territory (the ninth largest in the world, almost equal to the territory of the entire Western Europe, and exceeding in size the territories of four neighbouring Central Asian states, both in connection with the fact, that a great variety of natural conditions, of ecological conditions and of biological species is observed in Kazakhstan. These unique landscape and climate related conditions ensure the species richness th the flora of Kazakhstan, where there are known up to 6000 species of just vascular plants, up to 5000 species of fungi, 2000 species of algae, 500 lichens and 500 species of mosses, which are almost fully represented in the Herbarium of the IBF of RK MES.

It is specifically the preservation and constant reference to materials, collected 100,50 , 10 years ago that provides a unique opportunity to track the changes, the migration and the transformation of the vegetation both in a specific territory and in Kazakhstan as a whole. It is possible to reliably conduct the floristic and ecological monitoring studies based on the documented herbarium material.

The establishment of Herbarium was initiated in 1932, simultaneously with the establishment of the botanical sector within the Kazakhstan base of AS of USSR, which managers were Shishkin B.K. (from 1932), Popov M.G. (1936), Pavlov N.V. (from 1937). The initial Herbarium was partly formed with the material, sent from Leningrad (Saint Petersburg) and from the other academic centers of the former Soviet Union and from other countries of the world.

The specimens, collected in 1840-1860 in the territory of Kazakhstan by renowned botanists A.Shrenk, G.S. Karelin, I.P.Kirillov. I.G.Borschov, E.L. Regel is of greatest value.

(C) Sitpayeva G., Mukhtubayeva S., Kudabayeva G., 2018 


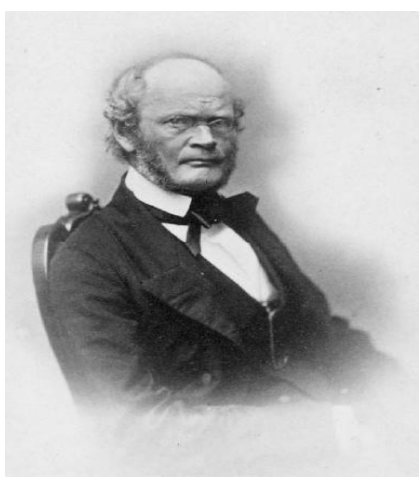

Alexander Gustav von Schrenk

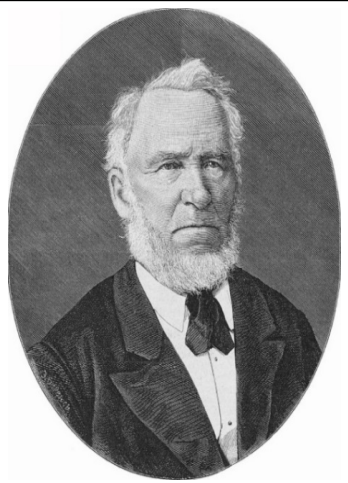

Edward Ludwigovich Regel

Later the Herbarium was supplemented with collections of world known scientists: N.V. Pavlov, G.K. Shishkin, M.N. Nevodovsky.

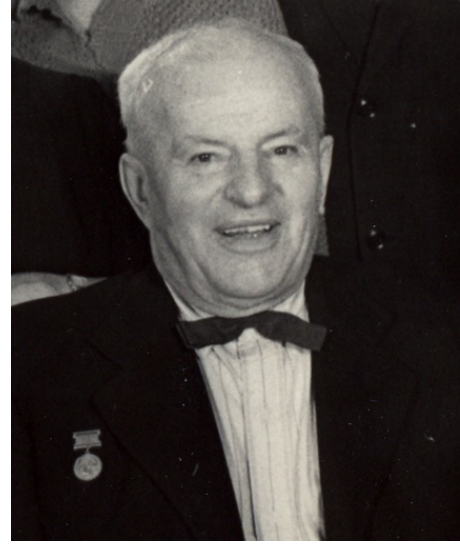

N.V. Pavlov

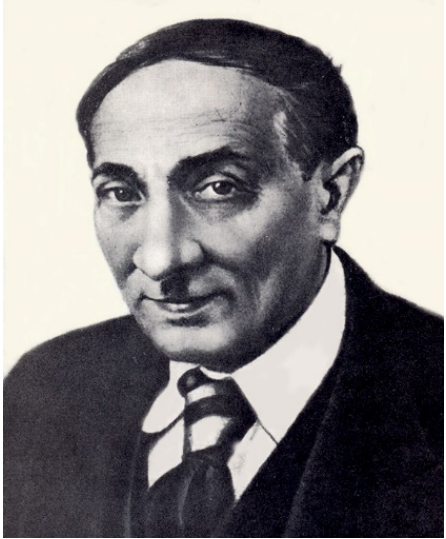

M.G. Popov

The Herbarium of the Institute of Botany and Phytointroduction was established with the work of five generations of Kazakhstani scientists, the collection of material did not stop even during the years, which were most difficult for the Republic.

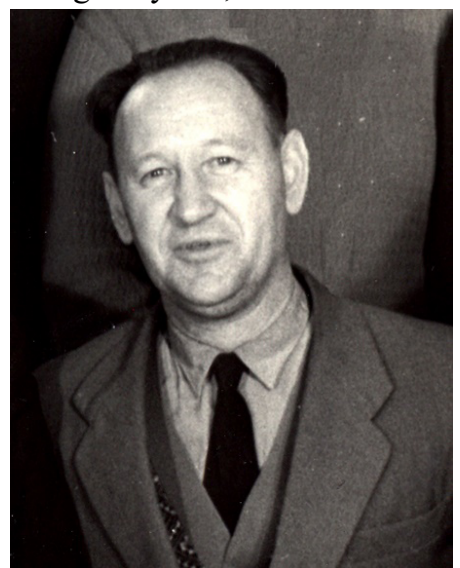

V.P. Goloskokov

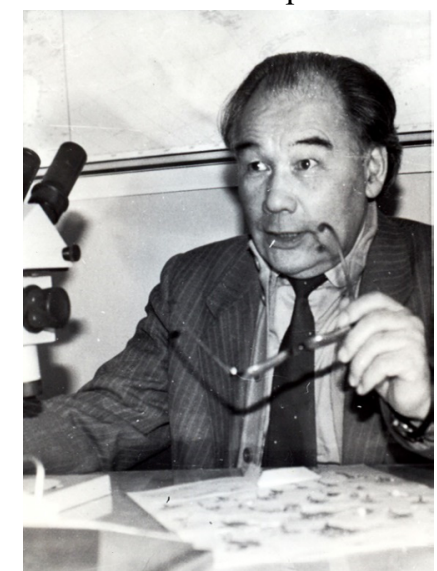

M.S. Baitenov

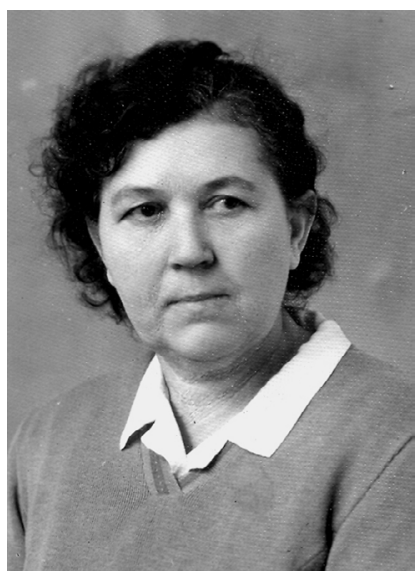

N.Kh. Karmysheva 
Later the collectors included V.P. Goloskokov, P.P. Polyakov, I.I. Roldugin, Z.V. Kubanskaya, B.A. Bykov, M.S. Baitenov, V.V. Fissyun, N.Kh. Karmysheva, A.P. Gamayunova, N.S. Filatova, A.N. Vassilyeva, A.O. Orazova, V.G. Tsagolova, N.L. Semiotrocheva, A.P. Gamayunova.

Considering the need for and the importance of preservation of herbarium collections a separate lab was organized - the Herbarium lab (under the supervision of P.M. Myrzakulov, B.A. Vintergoller), which was then included into the composition of the lab of the flora of higher plants.
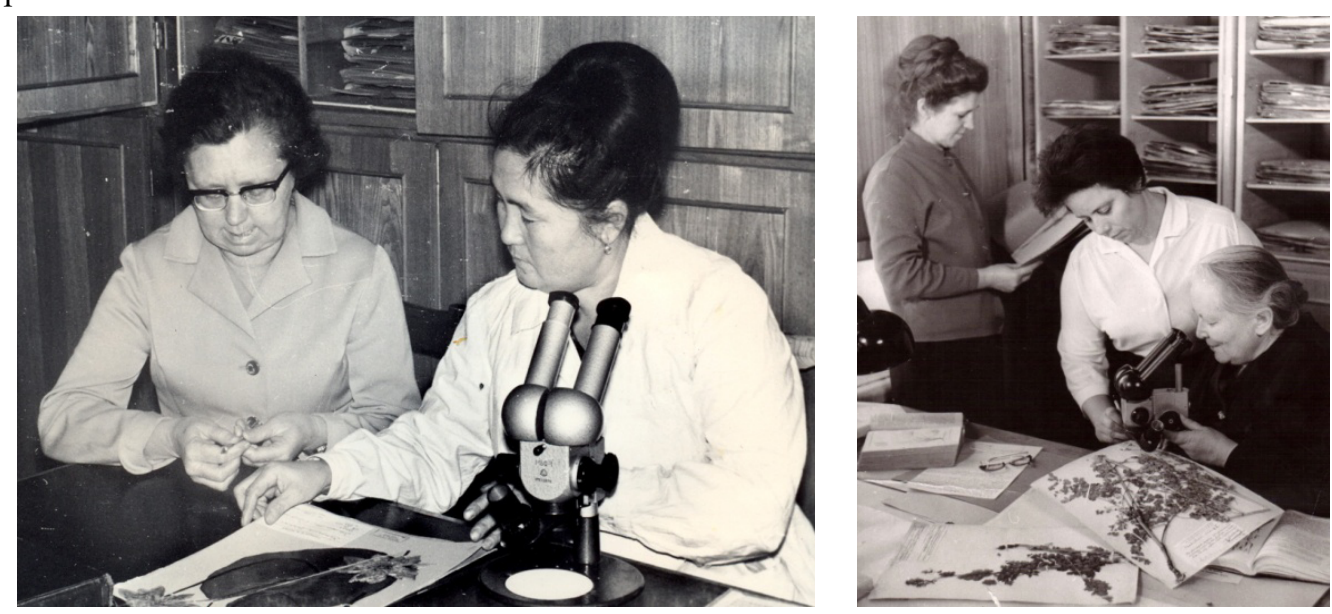

Employees of the Flora Department: V.V. Fissyun, A.O. Opazova A.N. Vassiliyeva, N.L. Semiotrocheva, A.P. Gamayunova

The most considerable contribution into the establishment of the Herbarium was made by the Institute employees in collecting and processing materials for the fundamental 9-volume "Flora of Kazakhstan" (1956-1966), and then, for the Illustrated Determiner of the Plants of Kazakhstan" (1969-1972).
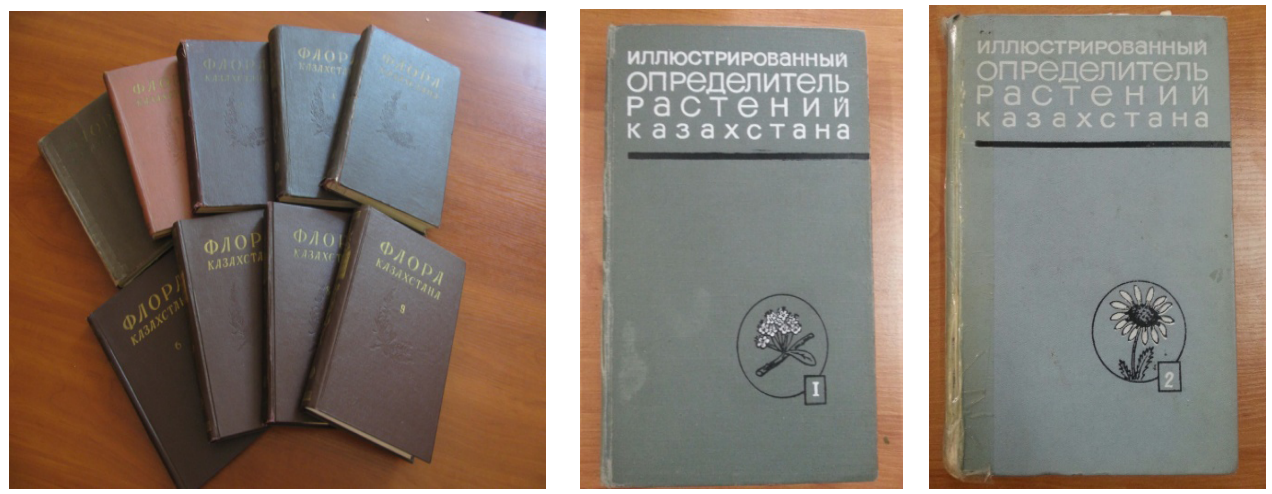

On the basis of the Herbarium collections, it became possible to publish the Determiner of the economically valuable genera of Graminae (A.P. Gamayunova, N.M. Kuznetsov, E.A. Medvedeva, 1948), Chenopodiaceae (V.P. Goloskokov, P.P. Polyakov, 1955), leguminous plants (V.P.Goloskokov, 1962), as well as the "Determiner of Weed Plants of Kazakhstan" (A.O. Orazova, 1972), "Flora and Vegetation of Aksu Jabagly Natural Reserve" (N.Kh. Karmysheva, 1973), "Dandelions of Kazakhstan and of Central Asia (A.O. Orazova, 1975), 16 issues of "Botanical Materials of the Herbarium of the Institute of Botany of AS of KazSSR" (1963-1989) and of the substantial number of floristic papers. 
In the course of implementation of monographic publications of N.Kh. Karmyshev "Flora and Vegetation of Western Slopes of the Talas Alatau" (1982), I.I. Roldutin "Water Plants" (1982, with co-authors), "Anthropogenic and Restoration Dynamic of Fir Tree Forests of North Tyan Shan" (1983), V.P. Goloskokov "Flora of Jungar Alatau" (1984), M.S. Baitenov "Astragals of Tyan Shan" (1977), "The High Mountainous Flora of North Tyan Shan" (1985), as well as of floristic articles, the materials of the Herbarium were not only used, but they were considerably supplemented with samples from the studied territories.

The floristic works of the lab employees, published over the years of independence: "Flora of Almaty Natural Reserve" (M.S. Baytenov, G.M. Kudabayeva, P.M. Myrzakulov, B.Zh. Toguzakov, 1991), "The Survay of the Flora of the Peak of South Altay" (Ye.B. Issayev, 1993), The Flora of the Northern Zaisan Peak (N.K. Aralbay, 1997), "The List of Vascular Plants of Kazakhstan" (S.A. Abdullina, 1999), "Flora of Kazakhstan” (M.S. Baitenov, 1999, 2001) are based on the study of herbarium materials.

The employees of the Flora Lab of the Institute of Botany and Phytointroduction perform the replenishment of collection materials, as well as its maintenance.

The employees of the lab, N.V. Nellina, M.P. Danilov, G.M. Kudabayeva, N.K. Aralbay, S.A. Abdullina, N.K. Zhaparova, V.A. Samoylova, as well as P.V. Vesselova, N.V. Schadrina, S.K. Mukhtubayeva, A.A. Kurmantayeva, A.A. Shormanova all contribute to the replenishment of the herbarium collection. L.M. Yanchenko was engaged in the work, related to the maintenance and the replenishment of herbarium collections for a long time. At present S.K. Mukhtubayeva serves as the Head of the Herbarium Group.

Structure of Herbarium: location of herbarium of samples according to A. Engler's system, with the inner separation, by 29 floristic districts, accepted for the flora of Kazakhstan (published in "the Flora of Kazakhstan"). In addition there are identified the specimens, collected in the territory of the Central Asia, of the European part of the USSR, of the Crimea and the Caucasus, Siberia and the Far East, as well as of foreign countries. All areas are marked on the herbarium sheets and they are stored in the general collection, without the separation by separate compartments.

The herbaria are the main source for the study of biological diversity of the plant world.

For the further preservation and development of the Herbarium collection as the basis for fundamental research within the framework of the program of "Replenishment, Study and Maintenance of Collections of Plants, Animals, Microorganisms and of Unique Genetic Banks for the Preservation of Biological Diversity of Kazakhstan", there was implemented the project "Replenishment, Preservation and Characteristics of the Herbarium Funds of Plants, Fungi, Lichens" (2008-2010). Along with the main tasks the establishment of the information database of high Vascular Plants started, stored in the herbarium collections of the Institute.

The program titled "Ensuring Preservation and Development of Collections of Plants, Animals, Microorganisms, Viruses and of Unique Genetic Pools as the Basis for Fundamental Research" became the continuation of these works in 2012-2014.

The implementation of this project provided not only for the preservation of collection, the replenishment of the Herbarium, but also the separation from the general Herbarium, of the collection of rare species of vascular plants, algae and fungi, including the ones that are parasites on the rare plant species. The taxonomic revision of the rare plant species in accordance with the International Biological Nomenclature Code was initiated. The establishment of the database of rare plant species, algae and fungi was an important stage in the program implementation. The model methodological recommendations for regional collections of rare plant species have been developed. 
Over the course of theme implementation there were developed the materials, collected from the mountain peaks of the south-east of Kazakhstan - Zainliyskiy (Ile-Alatau) and of Jungar Alatau (Zhetisu Alatau) (2012-2014), subjected to the growing anthropogenic impact; of mountainous territories of Kyrgyz Alatau, Karatau and of West Tyan Shan (2013), containing a considerable number of rare, endemic and relic plant species; of Kyzylorda Province, Karatau and of West Tyan Shan (2013), containing a considerable number of rare, endemic and relic species of plants; of Kyzylorda province (2014); the Chu-Ili mountains; of south macroslopes of the Jungar Alatau, of the SNNP "Altyn Emel”.

In the years 2013-2015 the employees of the lab participated in the implementation of the academic and technical program "Botanical Diversity of Wild Relatives of Cultured Plants of Kazakhstan as the Source of Enrichment and Preservation of Genetic Pool of Agricultural and Biological Diversity for the Implementation of Alimentary Programme" (Supervisor: Sitpayeva G.T.). For the optimal implementation of works the screening of collections of the Herbarium Fund of the Institute, there were determined the locations of the sites of concentration of the cultured plants wild relatives. The expedition research in the Kyrgyz Alatau, Tarbagatay, the Zaissan Bassin, the Zailiyskiy Alatau was performed, the valley of the river of Syr-Darya was explored and other have been researched.

In 2015-2017 the Institute implemented the state academic and technical programme "Sustainable Management of Genetic Resources of Public Botanical Gardens of the South-Eastern and of Central Kazakhstan - the specially protected natural territories of republican importance - in conditions of transition to "green economy", of which one of the main objectives is the preservation and development of the Herbarium.

The availability of collection of types is an important indicator characterizing the funds and the value of any Herbarium. In AA Herbarium of the Institute of Botany and Phytointroduction there are represented 354 type specimens. The greatest number of species described falls under the families of Fabaceae, Asteraceae. The lab employees have described over 250 new species of vascular plants for the flora of Kazakhstan. The largest number of new taxa was described by N.V. Pavlov, M.G. Popov, V.P. Goloskokov, M.S. Baitenov.

The promising focal area of the work in the Herbarium (AA) is the performance of scanning of herbarium sheets of the Main Herbarium, their digitalizing and the establishment of the photo collection.

About 1500 sheets, brought by employees of various labs are received by the Herbarium Group, from expeditions, for further multi-stage processing. The work, related to the exchange of herbarium materials with the collections funds of the CIS and non-CIS states.

The materials of the Herbarium of the Institute are needed both by scientists and by University students. The Herbarium premises are visited by many scientists and by employees of academic and manufacturing organisations, because the matters of rational use and of protection of natural plant richness of Kazakhstan attract the attention of the largest circle of specialists, teachers, students and of all conscientious people.

The introduction of contemporary methods of preservation and of further use of informational resources, contained in the Herbarium is one of the priority and promising objectives for further work. The established database for collection fund is already making it possible to use the available information more promptly.

The work done for the scanning of herbarium samples is the basis for the establishment of the virtual database for the species diversity of the Kazakhstan flora.

Globally, in practice, the collection are referred to the national heritage of the country. Thus, in many developed European states, such as France, the UK, Germany, the herbaria have 
the status of museum valuables. In Belarus, in 2006 the Herbarium was assigned the status of national heritage.

The Herbarium (AA) of the Institute of Botany and Phytointroduction is deemed to be the only Herbarium storage in which the entire species diversity of the Republic of Kazakhstan is represented. The richest Herbarium materials are deemed to be the necessary academic basis for the further development of botanical research in Kazakhstan, directed at the solution of important public objectives.

For the preservation and the use of information, contained in the collections of the Herbarium (AA) by the future generations, the Institute of Botany and Phytointroduction initiated the resolution of the matter, concerning the assignment of the National heritage to the Herbarium.

\section{REFERENCES}

1. Laboratory of the Flora of Higher Plants // Institute of Botany and Phytointroduction. Almaty, 2007. P. 62-73.

2. Laboratory of the Flora of Higher Plants // Yearbook (dedicated to the $80^{\text {th }}$ Anniversary of the Institute of Botany and Phytointroduction of RK CS MES). Almaty, 2012. P. 7-21.

3. Laboratory of the Flora of Higher Plants // Yearbook (dedicated to the $85^{\text {th }}$ Anniversary of the Institute of Botany and Phytointroduction of RK CS MES). Almaty, 2017. P. 48-67.

\section{ГЕРБАРНИЙ ФОНД (АА) ІНСТИТУТУ БОТАНІКИ ТА ІНТРОДУКЦІЇ РОСЛИН: ЗАСНУВАННЯ І ПЕРСПЕКТИВИ}

\section{Г. Сітпаєва, І. Мухтубаєва, Г. Кудабаєва}

РГП «Інститут ботаніки та фітоінтродукиї» РК НД МНС вул. Тимирязєва, 35 Д, Алмати 050040, Казахстан

e-mail:sitpaeva@mail.ru,mukhtubaeva@mail.ru,kgm_anita@mail.ru

Гербарій Інституту ботаніки та інтродукції рослин (АА) є складовою частиною національного надбання Республіки Казахстан.

Колекції Гербарію, в яких зберігається близько 259 тис. зразків мохів, голонасінних і покритонасінних, 150 тис. зразків грибів і лишайників, майже повністю репрезентують флору Казахстану, яка налічує понад 6 тис. видів судинних рослин, 500 видів мохів, 5 тис. видів грибів, 2 тис. видів водоростей, 500 видів лишайників.

Гербарні фонди почали формуватись у 1932 р., переважно за рахунок матеріалів, надісланих із різних ботанічних центрів. Надзвичайно цінними є збори 1820-1860 p.p. 3 території Казахстану А. Шренка, Г.С. Кареліна, І.П. Кірілова, І.Г. Борщова, Е.Л. Регеля. Пізніше Гербарій поповнився колекціями відомих ботаніків Н.В. Павлова, Г.К. Шишкіна, М.Н. Неводовського.

Значний вкладу формування колекцій Гербарію було здійснено співробітниками Інституту в ході підготовки 9-томного видання «Флора Казахстану (1956-1966) та «Визначника рослин Казахстану» (1969-1972). Ціла низка інших флористичних публікацій базувалася на вивченні колекцій видів рослин Гербарію. Серед цих публікацій варто згадати «Визначник бур'янів Казахстану» (Оразова, 1972), «Флора і рослинність заповідника Аксу Ябагли» (Кармишева, 1973), «Кульбаби Казахстану і Центральної Азії» (Оразова, 1975), «Флора і рослинність західних схилів Таласького Алатау» (Кармишев, 1984) тощо.

Гербарні колекції організовано за системою Енглера 3 розподілом на 29 флористичних районів, прийнятих у «Флорі Казахстану». Крім того, у Гербарії є збори 
Г. Сітпаєва, І. Мухтубаєва, Г. Кудабаєва

з Центральної Азії, європейської частини колишнього СРСР, Криму і Кавказу, Сибіру, Далекого Сходу та закордонних країн.

У Гербарії виконувалась низка проектів і програм, спрямованих на збереження, збагачення і розвиток колекцій, розпочалося формування бази даних судинних рослин та їхнього оцифрування.

У Гербарії зберігається 354 типових зразки видів рослин (типи й ізотипи), серед них - описані співробітниками Інституту 250 нових видів рослин.

Для збереження належного використання інформації, яка міститься у фондах Гербарію АА, Інститут ботаніки та інтродукції рослин ініціював процедуру надання Гербарієві статусу Національного надбання.

Ключові слова: гербарій АА, Інститут ботаніки та інтродукції рослин, Казахстан 